„Analecta Cracoviensia” 49 (2017), s. 7-28

DOI: http://dx.doi.org/10.15633/acr.2401

Marta Ficoń

Instytut Teologiczny im. św. Jana Kantego w Bielsku-Białej

\title{
Antydemoniczny charakter sakramentu Eucharystii
}

Łaska Boga Trójjedynego stanowi podstawę życia chrześcijańskiego, zapewnia jego rozwój oraz jest ostateczną bronią przeciwko potędze zła osobowego. Sakramenty jako znaki i narzędzia tej łaski jawią się zatem jako niezbędny element duchowego postępu, którego proces naznaczony jest wieloma przeszkodami, stawianymi głównie przez braki ludzkiej natury oraz aktywność ducha ciemności. Istnieją pozasakramentalne narzędzia walki z Szatanem, takie jak na przykład modlitwa o uwolnienie, sakramentalia (wśród nich egzorcyzmy), nabożeństwa pokutne, odnowa charyzmatyczna czy przebaczenie, ale nie zastąpią one sakramentalnych fundamentów życia łaską. Jest to jednak tylko początek drogi do doskonałości, ponieważ życie łaski otrzymane w sakramencie musi być ciągle podtrzymywane i kontynuowane, zarówno ze strony wiernego, jak i duszpasterzy. Działanie Chrystusa przez wylanie Jego Ducha w sakramencie musi być nakierowane na odpowiednie tory, by mogło kształtować osobę na wzór Jego osobowości. Takie podniesienie człowieka na wyższy poziom egzystencji musi objawiać się radykalną zmianą relacji do Chrystusa, który jest w nim obecny i towarzyszy mu. Konieczne jest kierowanie się Jego słowem w całym życiu, stałe budowanie z Nim więzi i formacja pod kierunkiem Ducha Świętego w Jego Kościele. Sakramenty nie są zatem eklezjologicznie wyabstrahowanym, subiektywnym odczuciem. Człowiek, podążając drogą łaski, nie idzie samotnie, chyba że samodzielnie postanowi odłączyć się od Chrystusa i Jego Mistycznego Ciała, ulegając diabelskim pokusom.

W poprzednim artykule ${ }^{1}$ przedstawiono znaczenie sakramentu chrztu i sakramentu bierzmowania oraz ich liturgii w walce $\mathrm{z}$ duchami ciemności. Jako

Zob. M. Ficoń, Antydemoniczny charakter sakramentu chrztu świętego i sakramentu bierzmowania, „Analecta Cracoviensia” 48 (2016), s. 25-40. 
sakramenty wtajemniczenia chrześcijańskiego, wyciskające niezatarte znamię przynależności do Chrystusa, mogą być przyjęte tylko raz w życiu, natomiast umocnienie łaską Bożą na co dzień przychodzi przede wszystkim w sakramentach Eucharystii oraz pokuty i pojednania. Sprawowanie sakramentów nie tylko nawiązuje do wydarzeń zbawczych, ale samo jest wydarzeniem zbawczym, czyli napełniającym miłością Trójcy Świętej oraz odrzucającym wszelkie zniewolenie złem. Sprawia to moc Ducha Świętego, który zawsze towarzyszył wszelkim działaniom Chrystusa. Sakramenty, a szczególnie Eucharystia, to aktualizacja i przekazanie misterium Paschy Chrystusa².

W Eucharystii Pascha Chrystusa jako przejście z ciemności do światła, ze stanu śmierci do pełni życia, uobecnia się w człowieku z odpowiednią postawą wewnętrzną ze szczególną mocą, jako że Eucharystia jest ośrodkiem całego życia chrześcijańskiego, z którym wiążą się i do której zmierzają pozostałe sakramenty, wszystkie kościelne posługi i dzieła apostolstwa - w niej zawiera się całe dobro duchowe Kościoła, czyli sam Jezus Chrystus 33. Stanowi również źródło wszelkiej łaski i odpuszczenia grzechów, uwalnia od grzechów powszednich i zabezpiecza przed śmiertelnymi ${ }^{4}$.

Zjednoczenie z Chrystusem w Komunii świętej poprzez przyjęcie z czcią Najświętszego Sakramentu, udział w liturgii eucharystycznej oraz adoracja eucharystyczna to aspekty tego sakramentu, które przyczyniają się do uświęcenia człowieka, całego Kościoła i świata oraz oddania chwały Trójcy Świętej $j^{5}$. Wymienione konsekwencje można nazwać wybitnie antydemonicznymi. W celu uzasadnienia tej tezy trzeba poddać analizie teologiczną i liturgiczną głębię sakramentu Eucharystii.

\section{Teologia sakramentu Eucharystii w ujęciu antydemonicznym}

Zanim nakreślimy znienawidzoną przez Szatana perspektywę spotkania człowieka z Najświętszym ze Świętych w sakramencie Jego Najświętszego Ciała

2 Por. K. Guzowski, Duch dialogujący, Lublin 2016, s. 235.

3 Por. Sobór Watykański II, dekret Presbyterorum ordinis, [w:] Sobór Watykański II, Konstytucje, dekrety, deklaracje, red. M. Przybył, Poznań 2002, 5; Benedykt XVI, adhort. apost. Sacramentum caritatis, Kraków 2007, 17-29 [dalej: sc].

4 Por. Komunia święta i kult tajemnicy eucharystycznej poza Mszą świętą, Katowice 1985, Wprowadzenie teologiczno-pastoralne 23.

5 Por. Ogólne wprowadzenie do Mszału rzymskiego: $z$ trzeciego wydania Mszału Rzymskiego: Rzym 2002, Poznań 2004, 16, 55, 69. 
i Krwi oraz następstwa tej interpersonalnej relacji, wypada najpierw przedstawić sposób, w jaki ziemska obecność i działalność Chrystusa oddziaływała na rzeczywistość demoniczną, oraz ukazać ustanowienie Eucharystii jako wydarzenie uobecniające w Kościele i przez Kościół Jego działalność zbawczą, w tym także egzorcystyczną.

\section{Jezus a demony}

Jezus Chrystus przyszedł na ziemię, by „przez śmierć pokonać tego, który dzierżył władzę nad śmiercią, to jest diabła, i aby uwolnić tych wszystkich, którzy całe życie przez bojaźń śmierci podlegli byli niewoli” ( $\mathrm{Hbr} 2,14-15$ ). Oddziaływanie Chrystusa niszczące aktywność duchów ciemności z czasów Jego ziemskiej działalności jest kontynuowane między innymi w Eucharystii. W uwielbionym człowieczeństwie obecny w sposób substancjalny i trwały pod postaciami eucharystycznymi Chrystus nadal daje życie i uwalnia z niewoli grzechu i diabła.

Gabriele Amorth, znany rzymski egzorcysta, uważał, że właściwie całe dzieło Odkupienia dokonane przez Chrystusa jest pierwszym, prawdziwym i wielkim egzorcyzmem ${ }^{6}$. To On uwalnia człowieka od złego wpływu Szatana, przychodzi, aby „zniszczyć dzieła diabła” (1 J 3, 8) i od Niego biorą początek wszelkie wyzwolenie oraz moc w walce ze złym duchem. Opisy ewangeliczne pełne są słów Jezusa ostrzegających przed lekceważącym traktowaniem wpływu demonicznego na umysł i zmysły człowieka, które kuszone są przede wszystkim wizją porzucenia wiary, prawdy, prawości i trwania w łasce (por. Łk 8, 12; J 8, 44; Mt 5, 37; 12, 43-45; 13, 39). Chrystus podkreślał, że Zły już przegrał (por. Łk 10, 18), został osądzony (por. J 16, 11), ale jego porażka całkowicie dopełni się dopiero na końcu czasów (por. Mt 25, 41), dlatego on i jego upadli aniołowie walczą z ludźmi, zwłaszcza służącymi Bogu (por. Łk 22, 31), by zniszczyć królestwo Boże, które nadeszło w osobie Jezusa Chrystusa. Oznaką tego przyjścia jest przede wszystkim działalność egzorcystyczna Syna Bożego (por. Łk 11, 20; 13, 32; Mt 12, 28).

Ewangelie synoptyczne często przekazują, że złe duchy dręczące opętanych wiedziały, z Kim mają do czynienia, i że dysponuje On Bożą mocą zdolną strącić je do czeluści „przed czasem” (Mt 8, 29). Ich perwersyjna i dyskretna aktywność nie mogła pozostać w ukryciu ani ostać się wobec Syna Bożego, działającego mocą Ducha Prawdy. Dlatego wołały z niepokojem i ostentacją: „Czego chcesz od nas, Jezusie Nazarejczyku? Przyszedłeś nas zgubić. Wiem,

\footnotetext{
6 Por. G. Amorth, Nowe wyznania egzorcysty, Częstochowa 1998, s. 40.
} 
kto jesteś: Święty Boga" (Mk 1, 24; por. 3, 11; Łk 4, 34). Takie reakcje złych duchów zauważane są również współcześnie, nie tylko przez egzorcystów. Osoby dręczone bądź opętane mają często wielkie trudności związane z uczestnictwem w Najświętszej Ofierze czy przyjmowaniem Ciała i Krwi Pańskiej oraz wykazują negatywne reakcje dotyczące adoracji Najświętszego Sakramentu? Obecny w nim realnie i substancjalnie Chrystus, „Święty Boga”, nadal uwalnia spod demonicznego wpływu oraz kieruje ku prawdzie i wolności przyjmujących Go z wiarą wiernych. Nie należy jednak wiązać Jego potęgi tylko i wyłącznie z działaniem nadzwyczajnym, które ostentacyjnie ujawni działanie demoniczne i przepędzi złego ducha. Jest to nikły procent wydarzeń w życiu chrześcijańskim.

Syn Boży nadal przemawia codziennie do człowieka na kartach Pisma Świętego, ostrzegając przed życiem bez Boga, które grozi niewolą Szatana i upadkiem w grzech (por. Łk 11, 24-26); jest obecny w zgromadzeniu zebranym w Jego Imię (por. Mt 18, 20), a w sposób szczególny daje siebie w Eucharystii. W ten sposób nadal zbawia człowieka od Złego, zarówno w swoim Corpus reale, jak i w Corpus mysticum.

Ustanowienie Eucharystii jako wydarzenie antydemoniczne Wszystko, co czynił i mówił Jezus, miało wymiar zbawczy, czyli wyzwalający z niewoli grzechu i złego ducha oraz napełniający Bożą łaską. W tej perspektywie wydarzeniem szczególnym i centralnym jest ustanowienie Eucharystii.

W Tajemnicy Paschalnej dokonuje się rzeczywiste uwolnienie ludzkości od zła i śmierci, dzięki miłości Boga wyrażonej w najbardziej radykalnym kształcie - w śmierci Syna Bożego na krzyżu. Już podczas ustanowienia Eucharystii Chrystus mówił o „nowym i wiecznym Przymierzu”, które zawiera się w Jego przelanej Krwi. Przy każdej celebracji mszy świętej Jezus Chrystus jest prawdziwym Barankiem Paschalnym, który dobrowolnie ofiarowuje się za nas, zawiązując w ten sposób owo Przymierze Boga z ludźmi, przerwane przez grzech, czyli przeniewierstwo i posłuszeństwo Szatanowi. Patrząc z tej perspektywy, ustanowienie Najświętszego Sakramentu przez Chrystusa i jego późniejsze sprawowanie w Kościele dokonuje się zawsze w kontekście wyzwolenia. Ostatnia Wieczerza była sprawowana zarówno jako pamiątka uwolnienia z niewoli egipskiej, jak i zapowiedź wyzwolenia definitywnego, głębszego i uniwersalnego. Jezus, ustanawiając sakrament Eucharystii, antycypuje

Por. L. Cristiani, Znaki obecności szatana we współczesnym świecie, tłum. J. Irzykowski, Gdańsk 1995, s. 177-178. 
i włącza weń ofiarę krzyżową oraz zwycięstwo zmartwychwstania, objawiając ich zbawczy sens. Wydarzenie Wielkiego Czwartku ukazuje, w jaki sposób ta śmierć w Jezusie stała się wyrazem największej miłości, a także ostatecznym wyzwoleniem człowieka od zła. Przyjmując ten dar, Kościół w Eucharystii zostaje włączony w akt ofiarniczy Chrystusa - nie tylko otrzymujemy wcielony Logos, ale zostajemy włączeni w dynamikę Jego ofiary, co powoduje ontologiczną przemianę ${ }^{8}$.

Działalność Jezusa i Jego Tajemnica Paschalna są największą klęską Szatana. Demoniczna władza nad światem i stworzeniem zapoczątkowana ongiś w Edenie (por. Rdz 3, 1-15) została zmiażdżona przez potęgę miłości Boga-Człowieka. Ludzkość była podtrzymywana w ciągu historii przez Bożą łaskawość, ale nie potrafiła prawdziwie kochać, będąc pod wpływem ducha ciemności. Do głębi prawdziwe i definitywne oblicze miłości przyszło do niej w osobie Jezusa Chrystusa, a dzięki Jego ofierze, uobecnianej codziennie w każdym zakątku świata, człowiek uwalniany jest nieustannie dynamiczną mocą Ducha z woli Ojca spod zniewalającej mocy Złego, który potrafi go wpędzić jedynie w duchową i fizyczną martwotę i inercję, aż do całkowitego upadku. Człowieka oddanego złu, żeby nie powiedzieć „opętanego”, można poznać po braku możliwości kochania. Chrystus rozbija tę duchową stagnację siłą swej Bożej miłości w każdej Eucharystii, jednocząc ze sobą jako Źródłem życia i wszelkiego szczęścia. Jeśli człowiek odpowie twierdząco na Jego inicjatywę, potęga Złego jest stopniowo kruszona, a jego panowanie nad światem powoli traci swą siłę i zasięg.

\section{Owoce Komunii świętej}

Konsekwencje zjednoczenia z Chrystusem w Komunii świętej można rozważać w dwóch wymiarach: jednostkowym (pogłębienie życia łaski i ochrona przed grzechem) oraz wspólnotowym (zjednoczenie Kościoła i dawanie świadectwa braciom). Wszystkie one funkcjonują jako tworzenie przepaści pomiędzy światem świętości, do którego przynależy Chrystus oraz zjednoczony z Nim człowiek, a światem zła i grzechu, do którego należy Szatan.

Dzięki Eucharystii wierni stają się uczestnikami komunii miłości wewnątrztrynitarnej, ponieważ Trójca Święta, jako Miłość sama w sobie, bezinteresownie obdarowuje życiem Bożym w sposób definitywny i skuteczny. W tym sakramencie tkwi źródło wszelkiej formy świętości, czyli pełni życia w Duchu Świętym, do której każdy jest wezwany. Chrystus uwielbiony, którego spożywa się w Eucharystii, to Chrystus „wypełniony Duchem”, dający życie w swym

8 Por. SC 9-11. 
uwielbionym człowieczeństwie. Dlatego jednoczy nas nie tylko ze swoją Osobą, ale także z życiodajnym Duchem, który wchodząc w ludzką rzeczywistość doczesną i życie zanurzone w historii, wynosi je na wyższy poziom, jednak nie odrywa człowieka od rzeczywistości ${ }^{9}$. Odcięcie od prawdy o sobie jest rzeczą diabelską, zorientowaną na to, by człowiek skupił się na samym sobie w zamkniętej szczelnie przestrzeni własnego ,ja”, natomiast Duch Prawdy otwiera go przede wszystkim na Boga i drugiego człowieka.

Bóg przychodzi do człowieka w Eucharystii, by stać się Pokarmem prawdy o Miłości, którą jest On sam, staje się Towarzyszem i Drogowskazem na drodze do wolności, zyskującej ukierunkowanie na przyszłe spełnienie i antycypującej w eschatologicznej jedności z Chrystusem - Zwycięzcą grzechu, śmierci i Szatana ${ }^{10}$. W tajemnicy Eucharystii Chrystus upodabnia do siebie człowieka, który jest w stanie osiągnąć tak głęboką jedność z Bogiem, że gdy dobrze przyjmuje Ciało Pańskie, staje się obrazem Syna Bożego. Człowiek zaczyna żyć „przez Chrystusa”, czyli prowadzić taką formę egzystencji, w której stopniowo przemienia się w Niego i która przekształca się w duchowy kult oddawany Bogu. Celebracja i adoracja Eucharystii przybliża z kolei do miłości Bożej, umożliwia osobiste do niej przylgnięcie, aż do zjednoczenia z Umiłowanym ${ }^{11}$.

Duchy ciemności dążą zaś do tego, by człowiek wpadł w niewolę grzechu ukazywanego jako prawdziwa wolność. Ludzka wolność w stanie grzechu jest jednak niepełna i zniekształcona - zostaje uzdrowiona dopiero w mocy Ducha, który oświeca również rozum, by można było właściwie rozpoznać przedmiot swych pragnień. Działanie Trójcy Świętej w Eucharystii chroni zatem przed grzechem, uzdalnia do codziennej walki z pokusami Oskarżyciela (zob. Ap 12, 10), wewnętrznie uzdrawia oraz wyzwala od nałogów i zniewoleń, a także stawia na drodze prawdziwej wolności i przywraca radość życia ${ }^{12}$.

Ofiara Chrystusa złożona na krzyżu i Jego zwycięskie zmartwychwstanie włączone w sakrament Eucharystii to tajemnica wyzwolenia i zbawienia. Jego zbawcza śmierć jest najbardziej radykalną formą miłości, ostatecznym uwolnieniem ludzi od zła i śmierci. Eucharystia zatem stanowi Nowe i Wieczne Przymierze we Krwi Pana-Baranka, który gładzi grzechy świata ${ }^{13}$.

\footnotetext{
9 Por. sc 8, 94; K. Guzowski, Duch dialogujący, dz. cyt., s. 245, 292.

${ }_{10}$ Por. SC 2, 30 .

${ }^{11}$ Por. SC 36, 70-71, 94.

12 Por. K. Guzowski, Duch dialogujący, dz. cyt., s. 307-308.

${ }_{13}$ Por. SC 9-10, 89.
} 
Jeśli chodzi o wymiar wspólnotowy Najświętszego Sakramentu, to warto zwrócić uwagę na refleksję Benedykta XVI, który podkreślił wagę wewnętrznej relacji między zwycięstwem Chrystusa nad złem i śmiercią a przynależnością do Mistycznego Ciała - Kościoła. Karmienie się Ciałem i Krwią Chrystusa pogłębia przynależność do Niego, a komunia ma zawsze dwa wymiary - horyzontalny i wertykalny, ponieważ w darze Eucharystii istnieje komunia z Bogiem jako źródło komunii międzyludzkiej. Zjednoczenie z Chrystusem w Eucharystii jest jednocześnie zjednoczeniem z wszystkimi, którym On się daje. Komunia wyprowadza z koncentracji na sobie, kierując ku Bogu i ludziom. Bóg w Eucharystii daje człowiekowi miłość agape, a on z kolei może ją przekazać innym ${ }^{14}$. Natomiast „ten, który rozprasza” (Łk 11, 23), czyli diabeł, zawsze stara się wprowadzać nieporozumienia i powodować konflikty, zarówno w relacji człowiek-Bóg, jak i w kontaktach międzyludzkich (zob. Rdz 3, 1-15). Sakrament Ołtarza jest zatem więzią jedności obecną w centrum życia Kościoła, a im większa wiara eucharystyczna w ludzie Bożym, tym głębsze uczestnictwo w życiu eklezjalnym ${ }^{15}$. Wierni jednoczą się z Bogiem i między sobą, starając się unikać podczas celebracji eucharystycznej wszelkiego indywidualizmu i podziału, ponieważ, jak stwierdza Vaticanum II, „mają wspólnego Ojca w niebie”, a oni „są dla siebie braćmi”"16.

Kolejnym owocem Komunii z Bogiem jest zobowiązanie do pomocy braciom i dostrzeganie Chrystusa w najmniejszych, by być dla nich na każdym etapie swej egzystencji świadkiem Eucharystii, z której czerpie się moc, natchnienie i pełny sens istnienia. Życie Eucharystią jest wezwaniem, by obecną w niej moc Chrystusa przełożyć na konkretną praktykę solidarności z każdym człowiekiem, ponieważ miłość w niej celebrowana $\mathrm{z}$ natury domaga się przekazania jej wszystkim - chce wszystkich objąć zbawieniem i wszystkich przyciągnąć do siebie. Dar Boga w Chrystusie to źródło nowej dynamiki w życiu w celu dawania świadectwa Jego miłości innym, aby je dobrowolnie przyjęli i mieli siłę do rozwoju prawdziwej wolności ${ }^{17}$. Dlatego Eucharystia stanowi lekarstwo na izolacjonizm i egocentryzm, jaki proponuje człowiekowi duch kłamstwa.

Oprócz wymiaru teologicznego charakter antydemoniczny posiada także wymiar celebratywny sakramentu Eucharystii.

\footnotetext{
${ }^{14}$ Por. sc 76, 89; Benedykt XVI, enc. Deus Caritas est, Katowice 2006, 14.

15 Por. sc 6.

${ }^{16}$ Ogólne wprowadzenie do Mszału rzymskiego..., dz. cyt., 95.

17 Por. SC 79, 82, 84-85.
} 


\section{Antydemoniczne elementy liturgii sakramentu Eucharystii}

Tajemnica Paschalna uobecniana podczas każdej Eucharystii jest wydarzeniem przełomowym w dziejach zbawienia i całkowicie destruktywnym dla rzeczywistości demonicznej, zarówno pod kątem celu, jak i zasięgu działania złych duchów. Umożliwia bowiem człowiekowi wejście w naruszoną przez grzech komunię ze Stwórcą oraz przywraca optykę dziękczynienia i oddawania Bogu chwały. Tymczasem poprzez wydarzenie przy drzewie poznania (por. Rdz 3, 1-15) Szatan wytrącił ludzkość z perspektywy bliskości ze Stwórcą, rzucając najpierw sugestię fałszującą prawdę o Bogu i o człowieku, a następnie podsuwając pokusę okazania nieposłuszeństwa Jego nakazom, ustanowionym przecież dla dobra stworzenia. Można te chwile nazwać swoistą „anty-Eucharystią”, podczas której wybrzmiewa demoniczne: „bierzcie i jedzcie”. Wojciech Maciążek stwierdza, iż „celebrowana wówczas antyliturgia wyłącza Boga z pierwotnej wspólnoty, zubożając relacje między ludźmi a światem. Tym samym Bóg staje się jedynie obserwatorem stojącym na uboczu, podczas gdy antyliturgia jest kontynuowana w dziejach. Punktem wyjścia w dalszym ciągu jest dzieło stworzenia, ale nie wyzwala ono w człowieku postawy wdzięczności i chwały, lecz staje się środkiem, przez który człowiek chce wywrzeć wpływ na Boga i otrzymać od Niego oczekiwaną odpowiedź"18.

Owa antyliturgia przejawia się nieustannie, zwłaszcza wtedy, gdy człowiek daje się zwieść „przewrotnemu geniuszowi podejrzeń” ${ }^{19}$, zamiast zawierzyć Bogu. Może to być „Zwykła” obojętność na sprawy Boże, poprzez uwikłanie w zło bardziej konkretne, na czele z kłamstwem, oszustwem, praktykowaniem magii i czarów, zwanych przez niektórych "diabelskimi sakramentami” ${ }^{20}$, aż po najpodlejsze zbrodnie. Szczególną, skrajną i przewrotną formą antyliturgii jest kult oddawany księciu ciemności i tak zwane „czarne msze”. Teologowie specjalizujący się w tematyce demonologicznej oraz egzorcyści, mający z nią szczególną styczność z racji swego posłania, wskazują, iż ludzie, którzy oddają cześć diabłu bądź sprawują ryty satanistyczne, pałają wręcz niewytłumaczalną nienawiścią do Najświętszego Sakramentu, dopuszczając się najczęściej zbezczeszczenia Ciała Pańskiego poprzez jego niegodne, świętokradcze przyjęcie, by je potem sprofanować podczas obrzędów „czarnej mszy”, w których

${ }_{18}$ W. Maciążek, Grzech pierworodny jako negacja wdzięczności, „Teologia w Polsce” 9 (2015) nr 1, s. 158.

19 Jan Paweł II, enc. Dominum et vivificantem, Wrocław 1994, 37.

${ }^{20}$ L. Cristiani, Znaki obecności szatana, dz. cyt., s. 77. 
wykorzystuje się teksty i modlitwy chrześcijańskie, lecz w sposób perwersyjny i bluźnierczy, parodiując katolicką mszę świętą. Nienawiść ta została nazwana „niewytłumaczalną”, ponieważ myśleniu ludzi oddanym Szatanowi brakuje logiki z racji tego, że jednym z dwunastu punktów paktu z diabłem, oprócz odrzucenia sakramentów i wypowiedzenia posłuszeństwa Bogu, jest uroczyste wyparcie się wiary eucharystycznej ${ }^{21}$. Skoro ci ludzie nie wierzą, że Chrystus jest obecny w konsekrowanej Hostii, to dlaczego z taką zaciekłością starają się ją zbezcześcić? Szczególną awersję do Eucharystii wykazują również w większości przypadków osoby opętane przez złego ducha, podobnie jak to miało miejsce w czasie ziemskiej działalności Chrystusa (por. Mk 1, 24).

W ten sposób zły duch pragnie uczynić życie człowieka pustym, nielogicznym i bezsensownym, by „uderzyć” w jakimś stopniu w Stwórcę, z którym nie może się w żadnej mierze równać. Niszcząc communnio między Bogiem a człowiekiem, „celebruje” swoistą antyliturgię, czyniąc starania, by ośmieszyć prawdziwy kult, sabotować oddawanie chwały Bogu i oderwać od Niego znienawidzonego człowieka, którego Stwórca kocha bezwarunkowo.

Natomiast liturgia eucharystyczna, którą zapoczątkował Chrystus, nakazując „to czynić na Jego pamiątkę" (Łk 22, 19), przywraca utraconą w wyniku winy człowieka jedność z Bogiem i uzdrawia jej wymiar doksologiczny. Warto przyjrzeć się też jej walorom chrystocentrycznym, a przez to antydemonicznym oraz odpowiedzieć na pytanie o relację między sakramentem Eucharystii oraz teologią i liturgią egzorcyzmów.

\section{Missale Romanum}

Chrystus jest obecny w swoim słowie wypowiadanym podczas sprawowania Eucharystii i to słowo nadal posiada moc zdolną przemieniać serca słuchaczy i wyrzucać złe duchy (por. Mk 1, 22. 27; Mt 7, 28; Łk 4, 32. 36). Słuchanie i kierowanie się „słowem z mocą” prowadzi do stania się odpornym na sugestie i ataki demonów. Eucharystyczna liturgia Słowa i liturgia Ofiary, nierozerwalnie ze sobą złączone w osobie Jezusa Chrystusa, stanowią dla człowieka przestrzeń nie tylko włączenia w communnio z Bogiem i z bliźnimi, wraz z wszystkimi tego pozytywnymi skutkami, ale również wyzwolenia spod nieznośnego jarzma grzechu i Złego.

${ }^{21}$ Por. M. Guerra Burgos, Satanizm i lucyferyzm jako formy alternatywnej i magicznej religijności naszych czasów, [w:] Egzorcyzmy dawniej i dziś, red. B. Barkowski, A. Posacki, Warszawa 2004, s. 97-98, 113-114; R. Laurentin, Szatan. Mit czy rzeczywistość?, tłum. T. Szafrański, Warszawa 1997, s. 159; G. Amorth, Nowe wyznania..., dz. cyt., s. 156. 
Mszał Rzymski zawiera liczne odniesienia do zwycięstwa Jezusa Chrystusa nad Szatanem i wzmiankuje wiele razy o wyzwoleniu człowieka od zła oraz przeniknięciu przez Boże światło.

We wszystkich okresach roku liturgicznego w czytaniach mszalnych pojawia się motyw rozproszenia ciemności przez światłość Syna Bożego, który przychodzi, by rozjaśnić „ciemności serca”"22, „to, co w ciemnościach ukryte” ${ }^{\text {23 }}$, rozproszyć „ciemności grzechu” ${ }^{24}$, „błędu” ${ }^{25}$ i „ciemności świata” ${ }^{26}$ oraz wyzwolić $\mathrm{z}$ „ciemności niewiary” ${ }^{27}, \mathrm{z}$,jarzma grzechu i śmierci”28, przenosząc ludzkość do „swego przedziwnego światła” (1 P 2, 9) ${ }^{29}$. Chrystus jest bowiem „Światłością świata”, dzięki której człowiek „nie będzie chodził w ciemności, lecz będzie miał światło życia” (J 8, 12) ${ }^{30}$.

Motyw ciemności, w których chce się ukryć zły duch, nie dotyczy tylko świata, grzechu i śmierci, ale również szeroko pojętego zła, rozumianego zarówno subiektywnie, jako złe skłonności ludzkiej natury, jak i obiektywnie, jako Zło osobowe, inicjujące wszelką aktywność sprzeciwiającą się Bogu. Wiele razy w modlitwach, litaniach i błogosławieństwach mszalnych pojawia się prośba o to, by uzdrawiająca moc Eucharystii oczyściła człowieka i jego serce od złych skłonności ${ }^{31}$ oraz od „każdego grzechu”, „śmierci wiecznej” i prowadziła ku zbawieniu ${ }^{32}$. Częstym błaganiem skierowanym do Jezusa jest zwłaszcza modlitwa o to, by w darze Eucharystii uwolnił człowieka od wszelkiego zła ${ }^{33}$, zarówno obecnego, jak i przyszłego ${ }^{34}$. Chrystus bowiem „uwolnił serca ludzi od zła, które niszczy przyjaźń, i usunął z nich nienawiść, która odbiera nam szczęście”35, a zatem oczyścił człowieka ze wszystkich możliwości, które mogłyby być zakotwiczeniem dla duchów ciemności. Następnie zniszczył moc

${ }^{22}$ Mszał Rzymski dla diecezji polskich, Poznań 1986, s. 17.

${ }^{23}$ Mszał Rzymski dla diecezji polskich, dz. cyt., s. 5, 12, 19.

${ }^{24}$ Mszat Rzymski dla diecezji polskich, dz. cyt., s. 15, 32*.

${ }_{25}$ Mszał Rzymski dla diecezji polskich, dz. cyt., s. 254, 264.

${ }^{26}$ Mszat Rzymski dla diecezji polskich, dz. cyt., s. 38, 382*.

${ }^{27}$ Mszał Rzymski dla diecezji polskich, dz. cyt., s. 218.

${ }^{28}$ Mszat Rzymski dla diecezji polskich, dz. cyt., s. $45^{*}$.

${ }^{29}$ Mszat Rzymski dla diecezji polskich, dz. cyt., s. 189, 199, 214, 229, 383*, 390*.

${ }^{30}$ Mszał Rzymski dla diecezji polskich, dz. cyt., s. 100, 244, 32*, 59".

${ }^{31}$ Por. Mszat Rzymski dla diecezji polskich, dz. cyt., s. 5, 8, 12, 15-16, 19, 44, 92, 100, 102, 251, 45".

${ }^{32}$ Por. Mszat Rzymski dla diecezji polskich, dz. cyt., s. 173, 77.

33 Por. Mszał Rzymski dla diecezji polskich, dz. cyt., s. 95, 375*, 390*, 396*, 106, 165', 8”, 170", (2).

34 Por. Mszał Rzymski dla diecezji polskich, dz. cyt., s. $392^{\star}, 27^{\prime \prime}$.

${ }^{35}$ Mszał Rzymski dla diecezji polskich, dz. cyt., s. 360*. 
inicjatora wszelkiego zła, które dotyka człowieka z zewnątrz. Jednak wciąż jeszcze Szatan walczy o ludzkie dusze, starając się je zwieść z drogi światłości, zanim Chrystus przyjdzie po raz drugi. Dlatego ważną częścią obrzędów eucharystycznych jest modlitwa Ojcze nasz, w której wierni błagają Ojca, by „zachował ich od złego" ${ }^{36}$. Embolizm, który rozwija ostatnią prośbę Modlitwy Pańskiej, jest błaganiem o uwolnienie całej wspólnoty wiernych od mocy zła, które nie stanowi jakiejś abstrakcji, ale oznacza Szatana, diabła, Złego, który przeciwstawia się nieustannie zamysłowi Boga i Jego dziełu odkupienia wypełnionemu w Chrystusie, a także uwalniającemu od grzechu i śmierci, które przez diabła weszły na świat ${ }^{37}$ : „Wybaw nas, Panie, od zła wszelkiego i obdarz nasze czasy pokojem. Wspomóż nas w swoim miłosierdziu, abyśmy zawsze wolni od grzechu i bezpieczni od wszelkiego zamętu, pełni nadziei oczekiwali przyjścia naszego Zbawiciela, Jezusa Chrystusa"38.

Prośba zawarta w embolizmie odwołuje się do łaskawości Boga, by zachował ludzkość nie tylko od Szatana, ale również od wszelkiego zła przeszłego, obecnego i przyszłego, którego on jest sprawcą i podżegaczem ${ }^{39}$, zwłaszcza zła wojny, nienawiści, grzechu i chaosu, które są głównymi znakami rozpoznawczymi jego działalności i które niszczą nadzieję pozwalającą oczekiwać eschatologicznego wypełnienia.

Wierni zatem proszą swego Pana podczas każdej Eucharystii, by zachował ich od wpływu demona i umocnił do dalszej z nim walki. Wskazują na to liczne wezwania obecne w całym Mszale Rzymskim.

Przy oczywistych nawiązaniach do wyzwalającej mocy Misterium Paschalnego bardzo często pojawiają się określenia o charakterze antydemonicznym, typu: „Twój Syn przez śmierć na drzewie krzyża uwolnił nas spod władzy szatana" ${ }^{40}$; „pójdziemy w uroczystej procesji za Chrystusem Zmartwychwstałym, aby wyznać naszą wiarę w Jego zwycięstwo nad śmiercią i szatanem”" ; „On zniweczył wszystkie podstępy szatana i nauczył nas zwyciężać pokusy do grzechu”"22; „zbliżają się dni Jego zbawczej Męki i chwalebnego Zmartwychwstania, dni, w których czcimy zwycięstwo Chrystusa nad złym duchem i wspominamy

${ }^{36}$ Mszał Rzymski dla diecezji polskich, dz. cyt., s. 369*.

37 Por. Katechizm Kościoła Katolickiego, Poznań 1994, 2851-2852 [dalej: ккк]; Ogólne wprowadzenie do Mszału rzymskiego, dz. cyt., 81, 153, 238.

${ }^{38}$ Mszat Rzymski dla diecezji polskich, dz. cyt., s. 145, 370-371*.

39 Por. KKK 2854.

${ }^{40}$ Mszał Rzymski dla diecezji polskich, dz. cyt., s. 116, 198.

${ }^{41}$ Mszał Rzymski dla diecezji polskich, dz. cyt., s. 181.

${ }^{42}$ Mszat Rzymski dla diecezji polskich, dz. cyt., s. $29^{*}$. 
Misterium naszego Odkupienia"43. W związku z tym w Mszale podkreślone jest również znaczenie krzyża jako znaku zwycięstwa Chrystusa nad Szatanem i śmiercią: „Ty postanowiłeś dokonać zbawienia rodzaju ludzkiego na drzewie Krzyża. Na drzewie rajskim śmierć wzięła początek, na drzewie Krzyża powstało nowe życie, a szatan, który na drzewie zwyciężył, na drzewie również został pokonany przez naszego Pana Jezusa Chrystusa"44.

Podczas liturgii Wigilii Paschalnej następuje odnowienie przyrzeczeń chrzcielnych, w których niegdyś wierni wyrzekali się „złego ducha i jego spraw”, a teraz postanawiają odrzucić znów „szatana, który jest głównym sprawcą grzechu"45.

Czytania mszalne uwypuklają też nieocenioną pomoc w walce ze złym duchem, jaką stanowi dla wierzącego Najświętsza Ofiara: „spraw, abyśmy umocnieni Najświętszym Sakramentem zawsze pokonywali zasadzki złego ducha” ${ }^{46}$; „prosimy Cię, aby Najświętszy Sakrament, który przyjęliśmy, bronił nas od wszelkich napaści złego ducha” ${ }^{47}$ czy „mocą tej Ofiary udziel Twojemu słudze łaski wytrwania aż do końca, aby w godzinie śmierci nie uległ podstępom szatana” ${ }^{48} \mathrm{i}$ „pokornie Cię błagamy o pomoc na godzinę śmierci, abyśmy pokonali zasadzki złego ducha i osiągnęli wieczna chwałę"49.

Podczas Eucharystii w ciągu całego roku liturgicznego celebrans wielokrotnie modli się o Boże wsparcie dla ludu: „Wszechmogący, wieczny Boże, wejrzyj łaskawie na naszą słabość $\mathrm{w}$ walce $\mathrm{z}$ mocami ciemności i wyciągnij w naszej obronie swoją potężną prawicę”5o ; „Panie, nasz Boże, daj nam przez święty post zacząć okres pokuty, aby nasze wyrzeczenia umocniły nas do walki ze złym duchem" "1.; „otaczaj odrodzonych w Chrystusie nieustanną opieką, aby odpierali ataki złego ducha i zachowali Twoją łaskę" 52 . Wypraszana podczas liturgii Boża pomoc wzywana jest bezpośrednio lub przez pośrednictwo aniołów ${ }^{53}$

${ }^{43}$ Mszat Rzymski dla diecezji polskich, dz. cyt., s. $35^{\star}, 143^{\star}$.

${ }^{44}$ Mszał Rzymski dla diecezji polskich, dz. cyt., s. $67^{*}$.

${ }^{45}$ Mszał Rzymski dla diecezji polskich, dz. cyt., s. 178 .

${ }^{46}$ Mszał Rzymski dla diecezji polskich, dz. cyt., s. 5'.

${ }^{47}$ Mszał Rzymski dla diecezji polskich, dz. cyt., s. 209'.

${ }_{48}$ Mszał Rzymski dla diecezji polskich, dz. cyt., s. 166".

${ }^{49}$ Mszał Rzymski dla diecezji polskich, dz. cyt., s. 179".

${ }^{50}$ Mszat Rzymski dla diecezji polskich, dz. cyt., s. 67.

${ }^{51}$ Mszał Rzymski dla diecezji polskich, dz. cyt., s. 62.

${ }^{52}$ Mszał Rzymski dla diecezji polskich, dz. cyt., s. 207.

53 W Święto Świętych Archaniołów Kościół przypomina, że aniołowie są duchami zesłanymi przez Boga na pomoc ludziom, „by im objawić plany Stwórcy” i „by ich bronić przed szatanem”. 
i świętych ${ }^{54}$ czy też przy użyciu sakramentaliów, takich jak święty olej: „Racz poświęcić sam, o Królu, [...] olej ten, ożywczy symbol, wbrew szatańskim uroszczeniom”55, czy też woda święcona: „Prosimy Cię, pobłogosław tę wodę, którą z ufnością się posługujemy, aby uprosić przebaczenie naszych grzechów i uzyskać ochronę przeciwko wszelkim chorobom i zasadzkom szatana" ${ }^{56}$, albo woda święcona z dodatkiem soli: „Prosimy Cię, Panie, spraw, niech wszędzie tam, gdzie padną krople tej poświęconej wody, ustaną napaści szatana i niech nas zawsze strzeże obecność Ducha Świętego" 57.

Liturgia eucharystyczna ma również związek z innym sakramentalium, które zostało ustanowione w szczególnym celu, a mianowicie istnieje tylko po to, by mocą Bożą i za pośrednictwem Kościoła uwalniać od wpływu złego ducha.

\section{Eucharystia a egzorcyzmy}

Jak już zostało wspomniane, ustanowienie Eucharystii i jej nieustanne sprawowanie aż po dzisiejszy dzień ma wymiar wybitnie antydemoniczny. Dlaczego więc ustanowiono obrzęd egzorcyzmów, skoro w Komunii świętej wierny spotyka się z samym Chrystusem - Zwycięzcą Szatana? Odpowiedź na to pytanie jest wieloaspektowa, ponieważ zawiera w sobie elementy dotyczące nie tylko sakramentologii i liturgiki, ale przede wszystkim teologii duchowości, antropologii teologicznej i demonologii. Najpierw zatem trzeba rozważyć podobieństwa obu celebracji i głębi teologicznej każdej z nich, by potem omówić różnice między nimi oraz rację bytu egzorcyzmów.

Trzeba najpierw rozgraniczyć sytuację człowieka, który prowadzi w swym życiu chrześcijańskim walkę duchową ze Złym, poddawany jest jego działaniu zwyczajnemu, czyli pokusom, bądź atakom lżejszego kalibru, a sytuacją człowieka w stanie opętania, który powinien poddać się egzorcyzmom większym,

Szczególną rolę w walce z diabłem pełni Archanioł Michał, który „stoczył walkę ze złymi duchami i nadal wspiera ludzi w walce ze złem (Ap 12, 7-9)", Mszał Rzymski dla diecezji polskich, dz. cyt., S. 192 '.

${ }^{54} \mathrm{Na}$ przykład we wspomnienie św. Antoniego opata tekst liturgiczny mówi o jego sławnym zwycięstwie nad mocami ciemności, dzięki łasce Bożej, która dla nas ma źródło przede wszystkim w Eucharystii, Mszał Rzymski dla diecezji polskich, dz. cyt., s. 5'. We wspomnienie św. Jadwigi Śląskiej modlimy się, by Najświętszy Sakrament „bronił nas od wszelkich napaści złego ducha”, a przez zasługi wspomnianej świętej zapewnił nam wieczny pokój po śmierci, Mszał Rzymski dla diecezji polskich, dz. cyt., s. 209'.

${ }_{55}$ Mszał Rzymski dla diecezji polskich, dz. cyt., s. 120.

${ }^{56}$ Mszał Rzymski dla diecezji polskich, dz. cyt., s. (3).

${ }^{57}$ Mszał Rzymski dla diecezji polskich, dz. cyt., s. (4). 
przewidzianym w Rituale Romanum do odprawienia przez kompetentnego kapłana za zgodą biskupa.

W tym pierwszym przypadku udział w celebracji Eucharystii, słuchanie Słowa Bożego oraz karmienie się Ciałem i Krwią Pańską są fundamentalną częścią życia duchowego, między innymi także walki ze Złym, który jest nieprzyjacielem Boga i wszystkiego, co wierni łączą z Jego zbawczym działaniem, dlatego reaguje gwałtowną nienawiścią wobec wszelkich obrzędów sakramentalnych ${ }^{58}$. Człowiek, który poddaje się ochronie Bożej w zjednoczeniu eucharystycznym, nie powinien jednak traktować Najświętszego Sakramentu jak mocy magicznej, która go ochroni przed złem, ale mieć pełną świadomość tego, że spotyka się w nim ze swoim Zbawcą, czerpiąc łaski do wzrostu duchowego.

Egzorcyści i inni kapłani wskazują na praktykę modlitwy, zarówno osobistej, jak i wspólnotowej, przyjmowania z wiarą sakramentów oraz życia zgodnego z Ewangelią jako podstawę życia chrześcijańskiego i „zwyczajne” środki łaski, niezwykle skuteczne, zarówno jeśli chodzi o codzienną walkę z mocami ciemności, jak i o przeciwdziałanie procesowi, który prowadzi do opętania diabelskiego ${ }^{59}$. List Kongregacji Nauki Wiary o niektórych normach dotyczących egzorcyzmów z 29 września 1985 r. napomina: „Pasterze powinni [...] przypomnieć nauczanie tradycji Kościoła o funkcji, jaką pełnią sakramenty i wstawiennictwo Błogosławionej Dziewicy Maryi, aniołów i świętych w duchowej walce chrześcijan z duchami kłamstwa"60.

Sytuacja zmienia się w drugim przypadku, kiedy doszło do opętania demonicznego. Wówczas Eucharystia i inne sakramenty stanowią nie tyle wyzwolenie, co raczej wsparcie i pokrzepienie na drodze do uwolnienia przez egzorcyzmy. Jako działania ustanowione przez Chrystusa i niosące z sobą łaskę Ducha Świętego sakramenty są źródłem umocnienia, ale nie całkowitego uzdrowienia i wybawienia od obecności diabła. Natychmiast pojawia się pytanie o przyczynę takiego stanu, skoro egzorcyzm bierze swą moc przede wszystkim z uobecnianej podczas każdej celebracji eucharystycznej Tajemnicy Paschalnej Chrystusa jako Jego zwycięstwa nad Szatanem, grzechem i śmiercią. W Eucharystii stoimy przecież po Krzyżem, na którym Chrystus składa

${ }_{58}$ Por. Rytuał Rzymski. Egzorcyzmy i inne modlitwy błagalne, Katowice 2002, 16.

59 Por. G. Amorth, Wyznania egzorcysty, Częstochowa 1997, s. 48, 85, 105, 114-115, 118, 149-150; G. Amorth, Nowe wyznania..., dz. cyt., s. 125, 145, 194, 199, 210-211; J. Szymborski, „Cały świat leży w mocy Złego" (1 J 5, 19), [w:] Egzorcyzmy dawniej i dziś, dz. cyt., s. 178; P. Towarek, Egzorcyzm. Historia, liturgia, teologia, Olsztyn 2013, s. 246-247.

${ }^{60}$ Kongregacja Nauki Wiary, list Inde ab aliquot annis, 29.09.1985, A AS 77 (1985), s. 1169-1170. 
w ofierze siebie samego dla wybawienia ludzkości z niewoli zła - krzyż jest miejscem Paschy Chrystusa i zawsze wyraża Jego władzę nad diabłem, dlatego podczas egzorcyzmu krzyż sprawia, że zły duch odchodzi ${ }^{61}$. W celu dotarcia do adekwatnej odpowiedzi prześledzimy pokrótce historię relacji pomiędzy sprawowaniem Eucharystii i obrzędami egzorcyzmów.

\section{Eucharystia i egzorcyzmy w starożytności chrześcijańskiej}

Już w pierwszych wiekach chrześcijaństwa ojcowie Kościoła wskazywali na bliskie związki między Najświętszym Sakramentem a obrzędem egzorcyzmów. Augustyn z Hippony (†430) w dziele O Państwie Bożym opisał przypadek, w którym Eucharystia miała działanie egzorcyzmujące. Odprawiona przez kapłana „ofiara Ciała Chrystusowego” z błaganiem o ustanie dręczenia przez złe duchy ludzi i zwierząt domowych stała się efektywnym środkiem przeciwko demonom: „Bóg natychmiast się zlitował i zło ustało”.

Jan Kasjan (†435), mnich i asceta, odpowiadając na pytanie dotyczące odmawiania opętanym Komunii świętej, stwierdził:

nie przypominam sobie, aby kiedykolwiek zabraniano jej opętanym, przeciwnie, sądzono, że jeśli tylko można, powinni oni przyjmować ją nawet codziennie. [...] Najświętsze Ciało nie ma przecież być pokarmem dla szatana, ale ma służyć opętanemu jako oczyszczenie i ochrona jego duszy i ciała. Wiadomo przecież, że przed Komunią świętą każdy zły duch, który osiadł już w człowieku lub dopiero usiłuje się ukryć w jego członkach, pierzcha niczym przed ogniem. Widzieliśmy niedawno, jak w ten właśnie sposób został uleczony abba Andronikus oraz wielu innych. Musimy bowiem wiedzieć, że jeśli ktoś pozbawia się Niebieskiego Lekarstwa, to tym bardziej będzie dręczył go nieprzyjaciel, a jego ataki będą tym straszliwsze i częstsze, im dłużej nieszczęsny będzie pozostawał bez tej duchowej pomocy ${ }^{63}$.

Jeśli chodzi o nauczanie Magisterium lokalnego, to Synod w Elwirze (ok. 306) postanowił, że Komunii świętej można udzielić ochrzczonemu i opętanemu tylko w godzinie śmierci ${ }^{64}$, natomiast I Synod w Orange (441) zezwalał już

${ }^{61}$ Por. P. Towarek, Egzorcyzm..., dz. cyt., s. 211, 213.

${ }_{62}$ Augustyn, Państwo Boże, tłum. W. Kubicki, Kęty 1998, XxıI 8.

${ }^{63}$ Jan Kasjan, Rozmowy z ojcami, t. 1, tłum. A. Nocoń, Kraków 2002, viI 34.

${ }^{64}$ Por. Synod w Elwirze 37, [w:] Acta Synodalia ann. 50-381, t. 1, red. A. Baron, H. Pietras, Kraków 2006, s. $55^{*}$. 
na udzielanie Komunii każdemu opętanemu ochrzczonemu, który podda się trosce i wskazówkom duchownych, by mógł być mocą sakramentu albo zachowany, albo oczyszczony od nękających go ataków demona ${ }^{65}$.

$\mathrm{Z}$ kolei pochodzący z x w. Pontyfikał rzymsko-germański zawiera dwa formularze mszy super daemoniacum, przeznaczonych dla opętanych przez złego ducha i potwierdzających więź egzorcyzmów z celebracją Eucharystii. Egzorcyzmu udzielano zwykle po mszy świętej odprawianej w intencji opętanego, który przybywał do kapłana po 40 dniach ascezy, by wyznać swe grzechy, wysłuchać mszy świętej, przyjąć Komunię świętą i trwać na modlitwie. Egzorcyści używali przeważnie formularza mszy salus populi zawierającego błaganie o uwolnienie opętanego $\mathrm{z}$ więzów demona. W wielu miejscach stosowano praktykę zanurzenia opętanego w kadzi z wodą święconą, po czym ubierano go i egzorcyzmowano. Wiązano również stułę wokół jego gardła, drugą wokół lędźwi, trzecią owijano nogi. W ten sposób brał on udział we mszy świętej i przyjmował, w miarę możliwości, Komunię świętą, po czym udzielano mu egzorcyzmu. Jeżeli uwolnienie nie nastąpiło po jednym dniu, opętany pozostawał całą noc w pomieszczeniu skropionym święconą wodą, a nazajutrz był ponownie egzorcyzmowany. Egzorcyzmy nie zawsze trwały długo - niektórzy autorzy piszą nawet o przypadkach uwolnienia przez przyjęcie Eucharystii ${ }^{66}$.

O połączeniu Eucharystii z praktyką egzorcystyczną zaświadczają też dane hagiograficzne, na przykład świętego Bernarda z Clairvaux (†1153), który niekiedy kładł na głowę opętanego Najświętszy Sakrament, oraz świętego Norberta $(\dagger 1134)$ czy świętej Hildegardy z Bingen $(\dagger 1179)^{67}$.

W Rytuale Rzymskim z 1614 r. jest też mowa o kapłanie, który musi odpowiednio przygotować się do odprawienia obrzędu egzorcyzmu. Przygotowanie egzorcysty obejmuje przede wszystkim mszę świętą, spowiedź i modlitwę ${ }^{68}$.

Poza kilkoma wyjątkowymi przypadkami natychmiastowych uwolnień od wpływu demona dzięki przyjęciu Najświętszego Sakramentu, we wspomnianych źródłach potwierdza się teza, że Eucharystia stanowi przemożne duchowe wsparcie, ochronę i w większości przypadków przygotowanie do obrzędu egzorcyzmu. Nie jest jednak środkiem czy narzędziem, którym Kościół posługuje się w uwalnianiu od złego ducha. Temu celowi służą

${ }_{5}$ Por. I Synod w Orange 13 (14), [w:] Acta Synodalia ann. 431-504, t. 6, red. A. Baron, H. Pietras, Kraków 2011, S. $18^{*}$.

${ }^{66}$ Por. P. Towarek, Egzorcyzm..., dz. cyt., s. 80, 83; G. Amorth, Nowe wyznania..., dz. cyt., s. 51.

${ }^{67}$ Por. P. Towarek, Egzorcyzm..., dz. cyt., s. 78.

${ }^{68}$ Por. P. Towarek, Egzorcyzm..., dz. cyt., s. 92, 148. 
egzorcyzmy. Wyjaśnienie owego zjawiska znajduje się przede wszystkim w Ewangelii, a potwierdzenie w doświadczeniach i świadectwach współczesnych egzorcystów.

\section{Eucharystia i współczesne egzorcyzmy}

W eksplikacji bardzo pomocne jest wzięcie pod uwagę przede wszystkim aspektu demonologicznego i antropologicznego. Na ten pierwszy wskazuje sam Jezus, zmuszając do odejścia ducha głuchego i niemego z pewnego chłopca i odpowiadając uczniom na pytanie o przyczynę tego, że oni nie mogli go z niego wyrzucić: „Ten rodzaj można wyrzucić tylko modlitwą i postem” (Mk 9, 29). Chrystus unaocznia zatem, że uwolnienie zależy od różnych czynników, wśród których można wymienić przede wszystkim rozróżnienie rodzaju złego ducha, jego „charakter” i miejsce w demonicznej hierarchii.

Ten drugi aspekt, antropologiczny, również jest niezwykle ważny, ponieważ przyczyny, czas trwania i intensywność opętania w większości przypadków zależą od woli i wiary opętanego. Dużą pomoc stanowi także wiara bliskich mu osób, grup modlitewnych i zaangażowanie egzorcysty. Jezus mówi do ojca opętanego chłopca w tej samej perykopie: „Wszystko jest możliwe dla tego, kto wierzy" (Mk 9, 23), a następnie, słysząc od niego wyznanie wiary, wyzwala jego syna z mocy złego ducha. Podobna sytuacja ma miejsce, gdy Jezus spotyka kobietę kananejską, której córkę ciężko dręczył zły duch: „O niewiasto, wielka jest twoja wiara; niech ci się stanie, jak chcesz!” (Mt 15, 28).

Egzorcyści wskazują, że niektórzy opętani nie są w stanie modlić się, przystępować do sakramentu pokuty i Eucharystii, ponieważ demon im na to nie pozwala, wytwarzając $w$ ich ciele opór. Te dwa sakramenty pełnią bowiem $\mathrm{w}$ procesie uwolnienia nieopisaną i fundamentalną rolę, stanowiąc element niezbędny na drodze do całkowitego wyzwolenia i gwarancję skuteczności egzorcyzmów ${ }^{69}$. Rytuał wskazuje, że wierny dręczony przez diabła powinien, w miarę możliwości, uciekać się do modlitwy, podjąć umartwienia, wyznawać często wiarę chrzcielną, przystępować częściej do sakramentu pojednania i posilać się Chlebem eucharystycznym. W skazana jest również modlitwa ze strony krewnych, przyjaciól, spowiednika i kierownika duchowego ${ }^{70}$. Te same sakramenty, wraz z modlitwą zaczerpniętą z Pisma Świętego i uczynkami miłości,

${ }^{69}$ Por. G. Amorth, Nowe wyznania..., dz. cyt., s. 57, 84, 162, 184; J. Kozłowski, $Z$ doświadczeń modlitwy o uwolnienie i uzdrowienie, [w:] Egzorcyzmy dawniej i dziś, dz. cyt., s. 74.

$7^{70}$ Por. Rytuał Rzymski. Egzorcyzmy i inne modlitwy błagalne, dz. cyt., 32. 
pełnią niezastąpioną rolę w życiu chrześcijańskim po uwolnieniu od wpływu złego ducha ${ }^{71}$.

Często zdarza się, że demon nie przeszkadza w przystępowaniu do sakramentów i w innych czynnościach chrześcijańskiego życia. Opętany może przystępować do Komunii świętej, czytać i rozważać Pismo Święte, modlić się, umacniać wiarę i praktykować miłość Boga i bliźniego ${ }^{72}$. Jednakże Ewangelie podają, że złe duchy zawsze reagowały natychmiast na obecność Jezusa, krzycząc i miotając ciałem opętanego oraz rozpoznając w Nim Syna Bożego (por. Mk 1, 25-26; 5, 7; 9, 17-29). Dlaczego więc duchy zła nie reagują w takich szczególnych przypadkach na obecność Najświętszego ze Świętych? Mają przecież nadal anielską, choć upadłą naturę, czyli wyższą od ludzkiej, przenikliwą inteligencję, która rozpoznaje bliskość Jezusa, czy to $\mathrm{w}$ formie naturalnej, czy pod postaciami eucharystycznymi. Znane są także pozabiblijne przykłady sytuacji, w których opętani miotani są z dużą siłą w obecności Najświętszego Sakramentu ${ }^{73}$. Wyjaśnienie można znaleźć w charakterystyce zjawiska opętania.

Szatan nie potrafi nic stworzyć sam z siebie, lecz konstruuje tylko nędzne imitacje dzieł Bożych i wykorzystuje je w złym celu. Demonolog kanonik Sandreau twierdził, że opętanie ma stanowić karykaturę Wcielenia, ale nie posuwa się aż do tchnięcia ducha, bo diabeł nie ma takiej mocy. Oznacza to, iż zły duch nie wkracza w duszę osoby opętanej i nie ożywia ciała, a jedynie, bez jego wiedzy, przejmuje nad nim kontrolę, zawsze oddziałując na układ nerwowy. Poza tym każdy demon ma odrębną „osobowość”, która powoduje, że niektóre $\mathrm{z}$ nich łatwo odchodzą, inne długo stawiają opór i potrafią wielokrotnie wracać. Natomiast rodzaj opętania związany jest ściśle z naturą i charakterem osoby opętanej. Zły duch może dowolnie naśladować jej sposób bycia i mówienia. Nie musi cały czas przebywać w osobie opętanej - powraca do niej, ilekroć tego zapragnie. Opętany czasami może okresowo uwolnić się od niego dzięki egzorcyzmom, a potem znowu mu ulec ${ }^{74}$.

W podobnym tonie pisał egzorcysta Amorth, który uważał, że opętanie nie polega na tym, że Szatan umiejscawia się w jakiejś osobie, choć takie może sprawiać wrażenie. Nie zamieszkuje też ciała jak dusza, nie jest bytem, który

${ }^{71}$ Por. Rytuał Rzymski. Egzorcyzmy i inne modlitwy błagalne, dz. cyt., 36.

${ }^{72}$ Por. J. Kozłowski, $Z$ doświadczeń modlitwy..., dz. cyt., s. 74, 193; G. Amorth, Nowe wyznania..., dz. cyt., s. 104, 160, 163.

73 Por. R. Laurentin, Szatan..., dz. cyt., s. 165; Egzorcyzmy dawniej i dziś, dz. cyt., s. 203.

74 Por. L. Cristiani, Znaki obecności szatana, dz. cyt., s. 74. 
przebywa w drugim bycie. Chodzi o oddziaływanie i wpływ, jaki wywiera na to ciało - to niejako duchowa siła, która może działać w umyśle, w całym ciele lub jego części. Amorth podkreślił, iż błędna jest idea zamieszkania jednocześnie w ciele Ducha Świętego i Szatana, podobnie jak dwie osoby zamieszkują ten sam pokój. Według niego są to podmioty duchowe mogące działać jednocześnie i w różny sposób w jednym człowieku. Jako przykład podał opętanie świętego ${ }^{75}$ : jego dusza i umysł przylegają w pełni do Boga oraz poddają się kierownictwu Ducha Świętego, który jest obecny, uświęca duszę, kieruje działaniami i myśleniem, może współistnieć z cierpieniem wywołanym przez siłę diabła ${ }^{76}$.

Odpowiedzią zatem na pytanie Leszka Misiarczyka: „Jak wyjaśnić teologicznie, że demony reagują mocniej na egzorcyzm [...] niż na sakramenty, w których przecież, jeśli można tak powiedzieć, obecność Chrystusa jest o wiele mocniejsza?"77, może być prawda o tym, że w chwili przystępowania do sakramentów zły duch chwilowo odchodzi, nie oddziałuje na człowieka w sposób nadzwyczajny tak, jak zwykł to czynić, manifestując swoją obecność. Obecność Chrystusa $z$ kolei powoduje u opętanego nieopisaną ulgę i wzmocnienie w dalszej walce duchowej. Egzorcysta ks. Jan Szymborski wymienił sakramenty jako działania Jezusa Chrystusa niosące z sobą łaskę Ducha Świętego albo uzdrawiającą, albo wzmacniającą. Eucharystię zaliczył do tej drugiej grupy ${ }^{78}$. Zatem spotkanie z Chrystusem w Eucharystii stanowi etap dojrzewania do miłości, której opętany zaniechał w przeszłości, co doprowadziło go do tego godnego

75 Dotykamy tutaj problemu opętania, które spotyka osoby oddane Bogu, biorące na siebie cierpienie związane z opętaniem diabelskim, najczęściej w celu ekspiacji za grzechy ludzkie i całkowitego oczyszczenia duszy, zwanego „oczyszczeniem biernym”. Nie chodzi tutaj o dręczenie zewnętrzne (obsessio), któremu poddawanych było wielu świętych. Zjawisko opętania (possessio) człowieka niewinnego jest dosyć słabo opisane w literaturze teologicznej. Niektórzy autorzy o nim nie słyszeli, niektórzy odrzucają taką możliwość. Znany jest jednak przypadek świętej Miriam Baouardy $(\dagger 1878)$, znanej także jako Maria od Jezusa Ukrzyżowanego, która doświadczyła w swym życiu opętania, zob. A. Brunot, Miriam. Mała Arabka, tłum. T. Szczepańczyk, Gdańsk 2006, s. 68, 76-81, 87-90. Léon Cristiani podaje kilka przykładów tego typu opętań, twierdząc, że egzorcyzmy w takich wypadkach czasem rozluźniają więzy opętania tak, że ofiara może przystępować do sakramentu pojednania i Eucharystii, by uzyskać nieocenione wzmocnienie w walce duchowej, por. L. Cristiani, Znaki obecności szatana, dz. cyt., s. 79-81, 88-109.

${ }^{76}$ Por. G. Amorth, Nowe wyznania..., dz. cyt., s. 204-205.

77 L. Misiarczyk, Opętania i egzorcyzmy - nowe wyzwania dla teologii XXI wieku, „Studia Nauk Teologicznych" 9 (2014), s. 251.

${ }^{78}$ Por. J. Szymborski, „Cały świat leży w mocy Złego” (1 J 5, 19)..., dz. cyt., s. 178. 
pożałowania stanu, jakim jest opętanie demoniczne ${ }^{79}$. Jeśli opętany zdoła przystąpić do Stołu Pańskiego, wtedy całkowite zaprzestanie oddziaływania diabelskiego dzięki egzorcyzmom jest bliższe i łatwiejsze. Po spotkaniu z Chrystusem w Eucharystii zły duch powraca, bo ma jeszcze w tym człowieku jakiś punkt zaczepienia, który może znajdować się w jego woli albo w niedoskonałości jego wiary. Gdyby w opętanym działał diabeł podczas Komunii świętej bądź wystawienia Najświętszego Sakramentu, konsekwencje były takie same, jak te opisane w Ewangeliach.

Życie Eucharystią nie dopuszcza do opętania, ponieważ jest to proces rozwoju miłości. Natomiast u człowieka, który nie kocha ani Boga, ani bliźniego, nigdy nie osiągnie wspomnianych wcześniej dobroczynnych skutków Komunii świętej i zły duch może w nim działać wedle uznania (zob. J 13, 27). Ponadto z opisów spotkań Chrystusa z opętanymi można wnioskować, że sama Jego obecność nie powodowała natychmiastowego i automatycznego wyrzucenia z nich demonów, chociaż była ona dla złych duchów nader niewygodna i męcząca. Chrystus w każdym przypadku używał wypowiedzi w formie imperatywnej, których używają po dziś dzień egzorcyści.

Eucharystia stanowi więc pokarm duszy, który wznieca w niej miłość i wzmocnienie $\mathrm{w}$ walce ze Złym w codziennym życiu, a zatem posiada cechy wysoce antydemoniczne, jednak nie została ustanowiona jako narzędzie do wyrzucania złych duchów. W przypadku opętania konieczne jest odprawienie egzorcyzmu większego, który Chrystus specjalnie w tym celu ustanowił oraz przekazał tę posługę i władzę nad demonami uczniom (por. Mk 6, 7. 13; Mt 10, 1. 8; Łk 9, 1; 10, 17). Wówczas Eucharystia stanowi niezbędną pomoc i oparcie na drodze do uwolnienia i odbudowania życia miłości, które człowiek zatracił poprzez grzech.

\section{ABstrakT}

Życie i dzieło Jezusa Chrystusa ma charakter zbawczy i wyzwalający z mocy złego ducha. $Z$ tej perspektywy ustanowienie Eucharystii i dawanie się wiernym jako Pokarm to dzieła wybitnie antydemoniczne, które uwalniają spod władzy duchów ciemności i stanowią niezbędną pomoc zarówno dla chrześcijan w codziennej walce duchowej, jak i dla opętanych na drodze do uwolnienia.

79 Pomijam tutaj szczególne i bardzo rzadkie przypadki opętania osób świętych, których granicą jest wola Boża i zgoda tych osób, zob. powyżej przyp. 75 . 
Również warstwa liturgiczna tego sakramentu zawiera wiele odniesień do chwalebnego zwycięstwa Chrystusa nad Szatanem i nieustanne błaganie o zachowanie ludzi od jego wpływu. Eucharystia nie stanowi jednak narzędzia do wyzwolenia opętanych $\mathrm{z}$ mocy demona, lecz jest fundamentalnym elementem procesu wyzwolenia poprzez egzorcyzm.

\section{SŁOWA KLUCzowe}

Eucharystia, Jezus Chrystus, Tajemnica Paschalna, wyzwolenie, Szatan, egzorcyzm, opętanie

\section{Abstract}

\section{Antidemonic feature of sacraments: the Eucharist}

The life and work of Jesus Christ are salvific and liberating from the power of the evil spirit. From this perspective, the institution of the Eucharist and giving Himself to the faithful as Nourishment are remarkably antidemonic deeds that free from the power of the spirits of darkness and are an indispensable aid for both Christians in the daily spiritual struggle and for the possessed on the path to liberation.

Also liturgical feature of the Sacrament contains many references to the glorious victory of Christ over Satan and incessant begging to keep people away from his influence. However, the Eucharist is not a tool for the liberation of the possessed from the power of the demon but constitutes a fundamental element of the process of liberation through exorcism.

\section{KEY WORDS}

The Eucharist, Jesus Christ, the Paschal Mystery, liberation, Satan, exorcism, possession

\section{BIBLIOGRAFIA}

Acta Synodalia ann. 50-381, t. 1, red. A. Baron, H. Pietras, Kraków 2006. Acta Synodalia ann. 431-504, t. 6, red. A. Baron, H. Pietras, Kraków 2011. Amorth G., Nowe wyznania egzorcysty, Częstochowa 1998.

Amorth G., Wyznania egzorcysty, Częstochowa 1997.

Augustyn, Państwo Boże, tłum. W. Kubicki, Kęty 1998.

Benedykt XVI, adhort. apost. Sacramentum caritatis, Kraków 2007.

Benedykt Xvi, enc. Deus Caritas est, Katowice 2006.

Brunot A., Miriam. Mała Arabka, tłum. T. Szczepańczyk, Gdańsk 2006. 
Cristiani L., Znaki obecności szatana we współczesnym świecie, tłum. J. Irzykowski, Gdańsk 1995.

Guerra Burgos M., Satanizm i lucyferyzm jako formy alternatywnej i magicznej religijności naszych czasów, [w:] Egzorcyzmy dawniej i dziś, red. B. Barkowski, A. Posacki, Warszawa 2004, s. 95-135.

Guzowski K., Duch dialogujacy, Lublin 2016.

Jan Kasjan, Rozmowy z ojcami, t. 1, tłum. A. Nocoń, Kraków 2002.

Jan Paweł II, enc. Dominum et vivificantem, Wrocław 1994.

Katechizm Kościoła Katolickiego, Poznań 1994.

Komunia święta i kult tajemnicy eucharystycznej poza Msza święta, Katowice 1985.

Kongregacja Nauki Wiary, list Inde ab aliquot annis, 29.09.1985, A AS 77 (1985), s. 11691170.

Kozłowski J., Z doświadczeń modlitwy o uwolnienie i uzdrowienie, [w:] Egzorcyzmy dawniej i dziś, red. B. Barkowski, A. Posacki, Warszawa 2004, s. 67-74.

Laurentin R., Szatan. Mit czy rzeczywistość?, tłum. T. Szafrański, Warszawa 1997.

Maciążek W., Grzech pierworodny jako negacja wdzięczności, „Teologia w Polsce” 9 (2015) $\mathrm{nr}$ 1, s. 149-159.

Misiarczyk L., Opętania i egzorcyzmy - nowe wyzwania dla teologii XXI wieku, „Studia Nauk Teologicznych" 9 (2014), s. 247-257.

Mszał Rzymski dla diecezji polskich, Poznań 1986.

Ogólne wprowadzenie do Mszału rzymskiego: z trzeciego wydania Mszału Rzymskiego: Rzym 2002, Poznań 2004.

Rytuał Rzymski. Egzorcyzmy i inne modlitwy błagalne, Katowice 2002.

Sobór Watykański II, dekret Presbyterorum ordinis, [w:] Sobór Watykański II, Konstytucje, dekrety, deklaracje, red. M. Przybył, Poznań 2002, s. 478-508.

Szymborski J., „Cały świat leży w mocy Złego” (1 J 5, 19), [w:] Egzorcyzmy dawniej $i$ dziś, red. B. Barkowski, A. Posacki, Warszawa 2004, s. 169-179.

Towarek P., Egzorcyzm. Historia, liturgia, teologia, Olsztyn 2013. 